\title{
Two new shallow water sea anemones of the family Actiniidae (Cnidaria: Anthozoa: Actiniaria) from British Columbia (NE Pacific)
}

\author{
N.P. Sanamyan', K.E. Sanamyan' ${ }^{1}$ N. McDaniel ${ }^{2}$ \\ ${ }^{1}$ Kamchatka Branch of Pacific Geographical Institute, Far-Eastern Branch of the Russian Academy \\ of Sciences, Partizanskaya Str. 6, 683000 Petropavlovsk-Kamchatsky, Russia. \\ e-mail: actiniaria@sanamyan.com \\ ${ }^{2}$ Neil McDaniel, Vancouver, British Columbia, Canada. \\ e-mail:neil.mcd@telus.net
}

ABSTRACT: Urticina clandestina sp.n. and Aulactinia vancouverensis sp.n. (family Actiniidae) are recorded from British Columbia, Canada. Urticina clandestina sp.n. is unique in possessing gonads on all mesenteries of first cycles and thus attaining intermediate position between Urticina and Cribrinopsis. Aulactinia vancouverensis sp.n. is a mediumsized rose-coloured species abundant near the northern end of Vancouver Island, but not widespread in southern British Columbia waters. It posses holotrichs in the column; their occurrence in related species is discussed.

How to cite this article: Sanamyan N.P., Sanamyan K.E., McDaniel N. 2013. Two new shallow water sea anemones of the family Actiniidae (Cnidaria: Anthozoa: Actiniaria) from British Columbia (NE Pacific) // Invert. Zool. Vol.10. No.2. P.199-216.

KEY WORDS: Sea anemones, Northeast Pacific, Actiniidae, Cnidaria, Anthozoa, Actiniaria, Urticina clandestina, Aulactinia vancouverensis.

\section{Два новых мелководных вида актиний семейства Actiniidae (Cnidaria: Anthozoa: Actiniaria) из Британской Колумбии (северо-восточная Пацифика)}

\author{
Н.П. Санамян ${ }^{1}$, К.Е. Санамян ${ }^{1}$, Н. МакДениел ${ }^{2}$
}

\footnotetext{
${ }^{I}$ Камчатский филиал Тихоокеанского института географии ДВО РАН, ул. Партизанская, 6, Петропавловск-Камчатский 683000, Россия. e-mail: actiniaria@sanamyan.com

${ }^{2}$ H. МакДениел, Ванкувер, Британская Колумбия, Канада.e-mail: neil.mcd@telus.net
}

РЕЗЮМЕ: Urticina clandestina sp.n. и Aulactinia vancouverensis sp.n. (семейство Actiniidae) описаны из района Британской Колумбии, Канада. Urticina clandestina n.sp. занимает промежуточное положение между родами Urticina и Cribrinopsis изза наличия гонад на всех мезентериях, в том числе и первых циклов, что не характерно для рода Urticina. Aulactinia vancouverensis sp.n. - актиния среднего размера, розового цвета, встречающаяся в большом количестве у северной части о. Ванкувер, но не широко распространенная в водах Британской Колумбии. У нее обнаружены голотрихи в нижней части колюмна. Обсуждается встречаемость этих нематоцист в родственных видах. 
Как цитировать эту статью: Sanamyan N.P., Sanamyan K.E., McDaniel N. 2013. Two new shallow water sea anemones of the family Actiniidae (Cnidaria: Anthozoa: Actiniaria) from British Columbia (NE Pacific) // Invert. Zool. Vol.10. No.2. P.199-216.

КЛЮЧЕВЫЕ СЛОВА: актинии, северо-восточная Пацифика, Actiniidae, Cnidaria, Anthozoa, Actiniaria, Urticina clandestina, Aulactinia vancouverensis.

\section{Introduction}

Actiniid sea anemones (members of the family Actiniidae) are a diverse group represented by many species in cold and temperate waters of the North Pacific. Many species of this group are large and colourful and constitute probably the most eye-catching component of benthic faunae at diver accessible depths. Despite a long history of investigation the taxonomy and species assignment of many North Pacific actiniid sea anemones is still confused with a number of mis-identifications and misapplied names established in the literature (see Sanamyan, Sanamyan, 2006). In part this is a result of objective difficulties in the identification of preserved specimens, which lose some species-specific characters (e.g. colour, shape of the tentacles, etc.), by which living specimens could be easily separated, and in part a result of incorrect interpretation of features and older descriptions (e.g. nematocyst batteries of Cnidopus were compared with occasional occurrence of similar nematocysts in Epiactis resulting in incorrect uniting of these genera, see Sanamyan, Sanamyan, 1998).

Underwater photography has advanced greatly in recent years, with well-documented, high quality photographs of sea anemones in their natural environment now available to taxonomists. This has significantly improved our knowledge of distribution, range of variation and habitat for many species of shallow water sea anemones. For example, it became clear that although the colouration of many species of sea anemones varied considerably, the colour pattern of almost every species has some rather stable species-specific features. This especially applies to various kinds of colour markings on the disk and tentacles. We believe that colour photographs of living species are a very important part of species descriptions, which may assist to identify the species in the future. In some species the colour model is more stable, in others more variable, so in each case it is necessary to take into account a whole complex of features characteristic of the species.

Numerous underwater photographs of sea anemones taken by one of us (N. McDaniel) in British Columbia revealed that sea anemones in this region are more diverse than was thought previously, with several species which have not been assigned to any previously known species. Two of them are described in the present paper.

\section{Material and methods}

Numerous specimens of both species described in the present paper were observed and photographed in-situ underwater to record colour, external appearance, position on substrate and to assess the degree of variation in these features. To study morphology collected specimens were relaxed in seawater with a bit of clove oil and fixed with formalin. For long term storage the specimens were transferred to alcohol.

To prepare histological sections the isopropanol-mineral oil technique was used (Buesa, Peshkov, 2009; Sanamyan, Sanamyan, 2012). This technique is much easier, faster and produces better results than traditional methods which use xylene. The method includes dehydration of a specimen in five changes of $100 \%$ isopropanol, then two changes of isopropanol mixed with mineral oil $\left(5: 1\right.$ and $2: 1$ at $\left.50^{\circ} \mathrm{C}\right)$, then mineral oil at $50^{\circ} \mathrm{C}$, and finally three changes of paraffin at $55-58^{\circ} \mathrm{C}$. Each stage took from 15 min to 2 hours depending on the size of the specimen (usually pieces less than $1 \mathrm{~cm}$ in thickness were used). For general histology 4 
$\mu \mathrm{m}$ sections were stained by one of several variants of Masson trichrome (Llewellyn, 2013) depending on which dye produced better results in a particular specimen or tissue. To study the distribution of nematocysts $10 \mu \mathrm{m}$ sections were stained first with $1 \%$ water solution of basic dye (e.g. Safranin which stains basitrichs and some types of holotrichs red, or Toluidine blue which stains the same cnidae black or deep blue), differentiated in slightly acid water (until stain is washed out from all tissues and only nematocysts remain stained), then the stain is fixed in $1 \%$ phosphomolybdic acid, and then the mesogloea may be stained by Aniline blue or Fast green FCF. We find this method very useful to reveal the real distribution of nematocysts in various tissues.

Size ranges of cnidae were studied on small pieces of macerated tissue. Cnidae were measured according the method of Hand (1954) (the reasons why we prefer this method are described in Sanamyan, Sanamyan, 2013).

Cnidae terminology follows Weill (1934) and Carlgren (1949), but classification of pmastigophores follows Schmidt (1969, 1972, 1974) with the modification of Hartog (1995) (see Sanamyan et al., 2012 for details).

Holotypes will be kept in Zoological Institute (St. Petersbourg, ZIN), paratypes in Kamchatka Branch of Pacific Geographical Institute (Petropavlovsk-Kamchatsky, KBPGI).

\section{Taxonomy}

\section{Family Actiniidae}

\section{Urticina clandestina sp.n.}

Table 1; Figs. 1-4.

MATERIAL EXAMINED. Holotype: ZIN No. 11328, according to the incoming catalog at the Sponges and Coelenterates Department of ZIN RAS, British Columbia, Canada: southern Strait of Georgia at the south end of Thetis Island, $48^{\circ} 59.353^{\prime} \mathrm{N}, 123^{\circ} 39.072^{\prime} \mathrm{W}$, low intertidal, August 9 2010, collector N. McDaniel. Paratypes: KBPGI 415/1 (+), 416/2 $\left(\mathrm{O}^{7}\right)$, same locality, two specimens.

DESCRIPTION. External structure. Specimens are rather large with the oral disk with an extended crown of tentacles attaining up to 15 $\mathrm{cm}$ in diameter. Formalin-preserved specimens are $70 \mathrm{~mm}$ in diameter and $35 \mathrm{~mm}$ high (holo- type) and $57 \times 42 \mathrm{~mm}(+)$ and $55 \times 32 \mathrm{~mm}\left(\mathrm{O}^{7}\right)$ (paratypes). The column is cylindrical; the circular adhesive pedal disk is usually of about the same diameter as the column. The column has numerous adhesive verrucae which are present over the whole of its surface but more numerous and more prominent in the distal half. All three preserved specimens bear a belt consisting of large and crowded gravel particles and broken shell firmly attached to verrucae on distal half of column, although the region near the margin is almost free of foreign matter (Fig. 1A, B). Verrucae, to which gravel particles are attached, have a thin cuticular covering (Fig. 2C). The colour of the pedal disk and column is usually red, sometimes pink, in the holotype it was bright vermilion red, darker at distal column; verrucae are of the same colour as the rest of column without any markings of different colour. There is a deep fosse and short capitulum (a feature characteristic of many actiniids).

The oral disk is flat and circular. All three preserved specimens have about 160 tentacles and on numerous underwater photographs from 100 to 160 tentacles are visible. The tentacles are always arranged decamerously in five cycles on outer half of the oral disk. They are short, occasionally, in extension, as long as half the diameter of oral disk, but usually much shorter, and thick, with blunt rounded tips, all of about the same length, inner may be slightly thicker than outer. In preserved specimens the tentacles are longitudinally striated. Underwater photographs of living specimens display considerable variation of colour and shades of oral disk and tentacles but a colour model is more or less stable and characteristic. The background colour of the oral disk varies from bright to dull red, olive-green, gray, blue or dirty yellow. The bases of the tentacles of some specimens are outlined by short thin red radial lines running on the oral disk. In some specimens these lines may be quite well developed (Fig. 1C), in others they are feebly marked or even absent (Fig. 1E, F). The background colour of the tentacles is similar to the colour of the oral disk. Each tentacle at the base and in the middle has a whitish or rose coloured transverse band, encircling it completely or embracing from oral and lateral sides only; these bands are separated by wider darker reddish band. On the oral sides of the tentacles 
Table 1. Size ranges (length $\mathrm{x}$ width, in microns) and distribution of cnidae of Urticina clandestina sp.n. Letters in brackets correspond to letters in Fig. 4. "N" - ratio of number of specimens in which each cnidae was found to number of specimens examined.

Таблица 1. Размеры (длина х ширина, в микронах) и распределение стрекательных капсул Urticina clandestina sp.n. Буквы в скобках соответствуют буквам на рис. 4. "N" - отношение количества экземпляров, в которых данный тип книд был найден, к количеству исследованных экземпляров.

\begin{tabular}{|l|l|c|c|}
\hline Body region & \multicolumn{1}{|c|}{ Cnidae } & Size ranges $(\mu \mathrm{m})$ & $\mathrm{N}$ \\
\hline Column & (a) basitrichs (rare) & $6-13 \times 1.5-2$ & $2 / 3$ \\
\hline & (b) basitrichs (common) & $15-29 \times 2-3.5$ & $3 / 3$ \\
\hline & (c) p-mastigophores A (common) & $20-29 \times 3.5-7$ & $3 / 3$ \\
\hline Tentacles & (a) spirocysts (see text) & $19-41 \times 2-3$ & $3 / 3$ \\
\hline & (b) basitrichs (common) & $15-25 \times 2-3.5$ & $3 / 3$ \\
\hline & (c) p-mastigophores A (see text) & $25-31 \times 5-7$ & $3 / 3$ \\
\hline Actinopharynx & (a) basitrichs (numerous) & $35-50 \times 5.5-8.5$ & $3 / 3$ \\
\hline & (b) p-mastigophores A (common) & $28-40 \times 5-8$ & $3 / 3$ \\
\hline Filaments & (a) basitrichs (rare) & $13-17 \times 1.5-2$ & $3 / 3$ \\
\hline & (b) basitrichs (common) & $20-32 \times 2.5-3.5$ & $3 / 3$ \\
\hline & (c) p-mastigophores A (common) & $23-40 \times 4.5-8$ & $3 / 3$ \\
\hline & (d) p-mastigophores B1 (common) & $42-70 \times 5.5-8$ & $3 / 3$ \\
\hline
\end{tabular}

whitish bands may be V-shaped. The actinopharynx and siphonoglyphs are always red.

Internal structure. Marginal endodermal sphincter muscle is strong, circumscribed, oval; its size on cross sections of two sectioned specimens was $3.3 \times 1.8 \mathrm{~mm}$ and $2 \times 1 \mathrm{~mm}$. The sphincter usually has one central lamella which varies considerably in shape and degree of development: the lamella may be thick and prominent (Fig. 2A) or short, or thin and inconspicuous (Fig. 2B). Radial muscles of the oral disk and longitudinal muscles of the tentacles are mainly mesoectodermal, but vary from ectomesogloeal to ectodermal (Fig. 3A). Circular endodermal columnar muscles are well developed on a whole column but absent on the tops of verrucae (Fig. 2A, C). Actinopharynx with two deep siphonoglyphs supported by directives. The thickness of the mesogloea of the siphonoglyphs is about the same as in rest of actinopharynx, but endoderm is significantly thicker, up to 5-7 times thicker than on other parts of actinopharynx.

The mesenteries are arranged decamerously in four cycles: $10+10+20+40$, although decamerous symmetry is violated by additional pairs of the mesenteries of third and fourth orders (Fig. 3B). Occasionally small mesenteries of the fifth cycle may be present. The number of mesenteries is the same distally and proximally and almost identical with the number of the tentacles. The mesenteries of all orders (excepting fifth, when present) may be perfect. Mesenteries have large oral stomata (up to $5 \mathrm{~mm}$ diameter) and small marginal stomata (about $0.5 \mathrm{~mm}$ diameter). Retractor muscles are rather strong, diffuse to restricted. In most mesenteries the retractor has a pennon on the side closer to the body wall (Fig. 3B, arrows). Parietal parts of the longitudinal muscles on the mesenteries between the retractor and body wall are well developed and sometimes form a small flap at the side adjacent to the body wall. Well developed parietobasilar muscles form a long free flap. Mesogloea of the outer part of the mesenteries (closer to body wall), in the region of the parietobasilar muscles, contains oval or elongate lacunae arranged into a single series, a feature reported also for other species of Urticina and related genus Cribrinopsis. Basilar muscles are well developed. Mesenteries of all orders, including directives, are fertile. Oocytes are up to $500-600 \mu \mathrm{m}$ and spermatic vesicles to $150-200$ $\mu \mathrm{m}$ in diameter.

The sexes are separate, no embryos were found in examined specimen.

Cnidom. Spirocysts, basitrichs, p-mastigophores A and p-mastigophores B1 (see Fig. 4 and Table 1 for size ranges and distribution). Pmastigophores $\mathrm{A}$ in the tentacles are common 

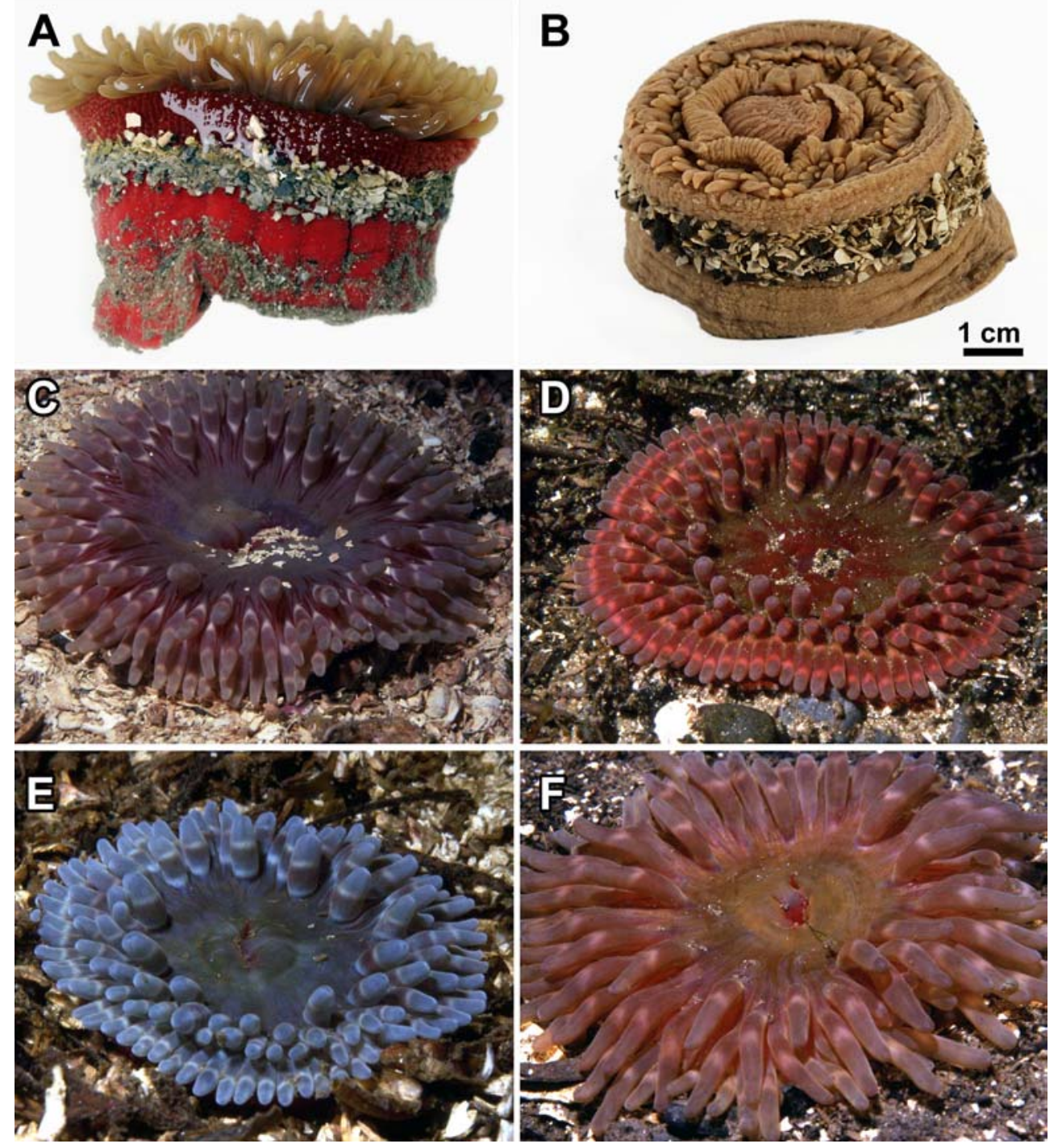

Fig. 1. Urticina clandestina sp.n., external appearance.

A - holotype, freshly collected, side view; B - holotype, preserved; C-F — specimens in natural habitat.

Рис. 1. Urticina clandestina sp.n., внешний вид.

A — голотип, сразу после сбора, вид сбоку; В — голотип, фиксированный; C-F - экземпляры в естественной среде обитания.

only on aboral sides of bases of outer tentacles, but not present on other parts of outer tentacles and in inner tentacles. On the other hand, spirocysts are numerous on all tentacles, but are rare on aboral sides of bases of outer tentacles. Types and size ranges of nematocysts in different parts of column are different. On the proximal half of the column (which is free from the gravel) and on the pedal disk only large basitrichs $(23-29 \times 2.5-3.5 \mu \mathrm{m})$ are present. In the region covered by gravel all three types of nematocysts are present (see Table 1); the size of large basitrichs here is somewhat smaller $(17-26 \times 2-3 \mu \mathrm{m})$. In the marginal region of the column, which is free from gravel, small basitrichs are not present, large basitrichs are 


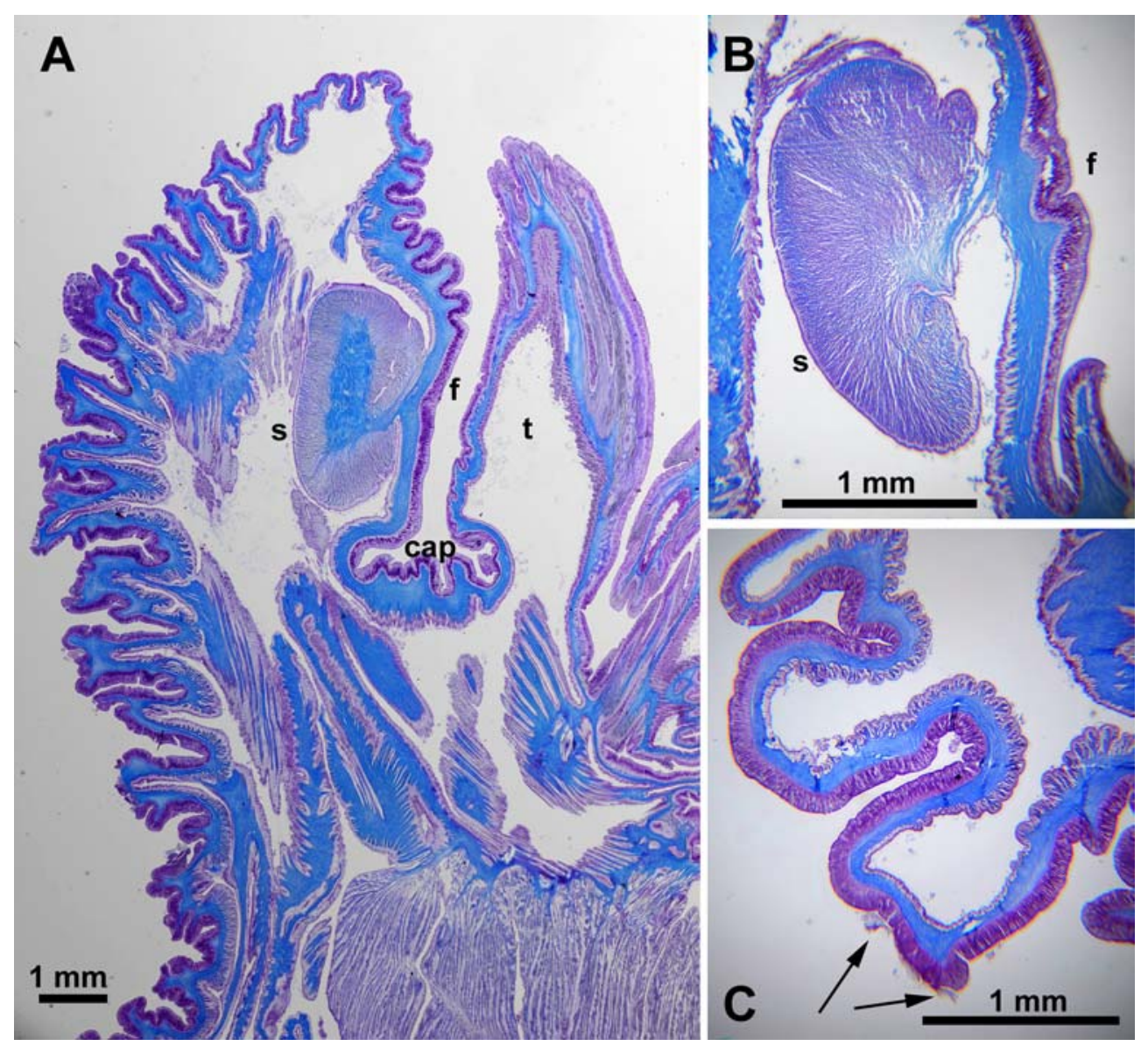

Fig. 2. Urticina clandestina sp.n., cross sections.

A - longitudinal section through distal column (specimen KBPGI 415/1) showing verrucae on column, deep fosse, circumscribed marginal sphincter and short capitulum between the bottom of the fosse and base of the tentacle, note thick main lamella of the sphincter on this section; B - different looking marginal sphincter of another specimen (KBPGI 416/2), note inconspicuous main lamella; C - longitudinal section through columnar verrucae, note remnants of cuticle on the top of verruca (arrows).

Abbreviations: cap — capitulum; $\mathrm{f}$ - fosse; $\mathrm{s}$ - marginal sphincter; $\mathrm{t}$ - tentacle.

Рис. 2. Urticina clandestina sp.n., гистологические срезы.

A — продольный срез через дистальную часть колюмна (экземпляр KBPGI 415/1), показывающий верруки на колюмне, глубокую фоссу, циркумскриптический маргинальный сфинктер с толстой центральной ламеллой и короткий капитулюм между дном фоссы и основанием щупалец; В - маргинальный сфинктер другого экземпляра (KBPGI 416/2) со слабо развитой центральной ламеллой; С - продольный срез через верруки колюмна, видны остатки кутикулы на вершине верруки (стрелки).

Сокращения: сар — капитулюм; f — фосса; s — маргинальный сфинктер; $\mathrm{t}$ - щупальце.

smaller $(15-22 \times 2-2.5 \mu \mathrm{m})$ and p-mastigophores $\mathrm{A}$ are rare. The $\mathrm{V}$-shaped funnel on the shaft of p-mastigophores B1 in filaments may be poorly defined and this cnida in unfired condition resembles b-mastigophore or basitrich rather than p-mastigophore. However, it is the same cnida which occurs in filaments of other species of Urticina and Cribrinopsis (where the $\mathrm{v}$-shaped funnel may be more obvious) and in other actiniids (see Hartog, 1987).

HABITAT. The species is always found buried in coarse sand or gravel with the pedal disk attached to solid objects like buried stones or rock. Only the oral disk with the tentacles is visible on the surface. Contracted specimens are usually hidden by overlying sediment. The spe- 


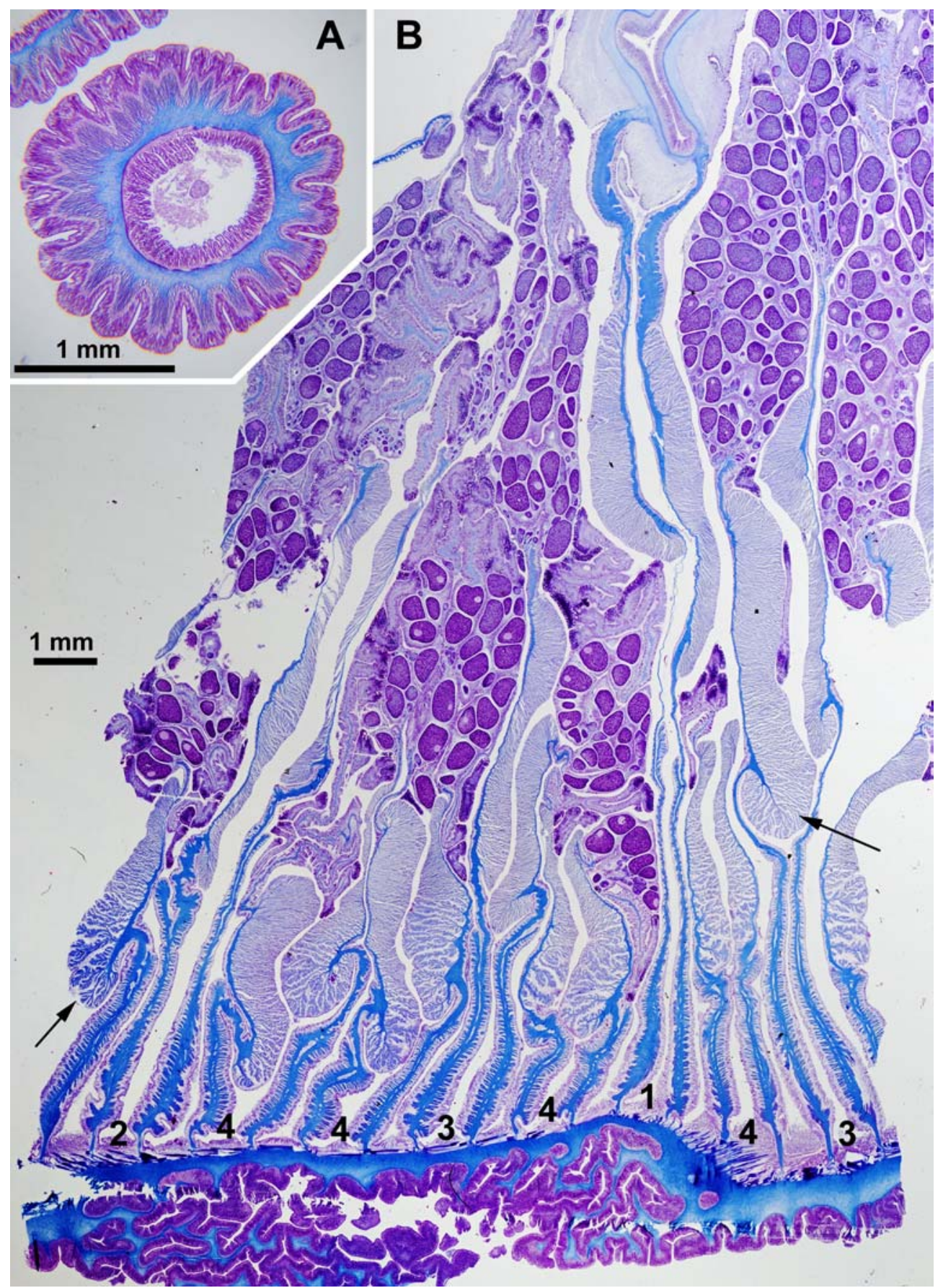

Fig. 3. Urticina clandestina sp.n., cross sections.

A - transverse section through the tentacle (specimen KBPGI 416/2); B - transverse section through the column (specimen KBPGI 415/1), cycles of mesenteries are marked by numbers, note the pennon of retractor muscles (arrows). Рис. 3. Urticina clandestina sp.n., гистологические срезы.

A — поперечный срез через щупальце (экземпляр KBPGI 416/2); B — поперечный срез через колюмн (экземпляр KBPGI 415/1), циклы мезентериев отмечены цифрами, стрелками отмечены отростки ретракторов. 


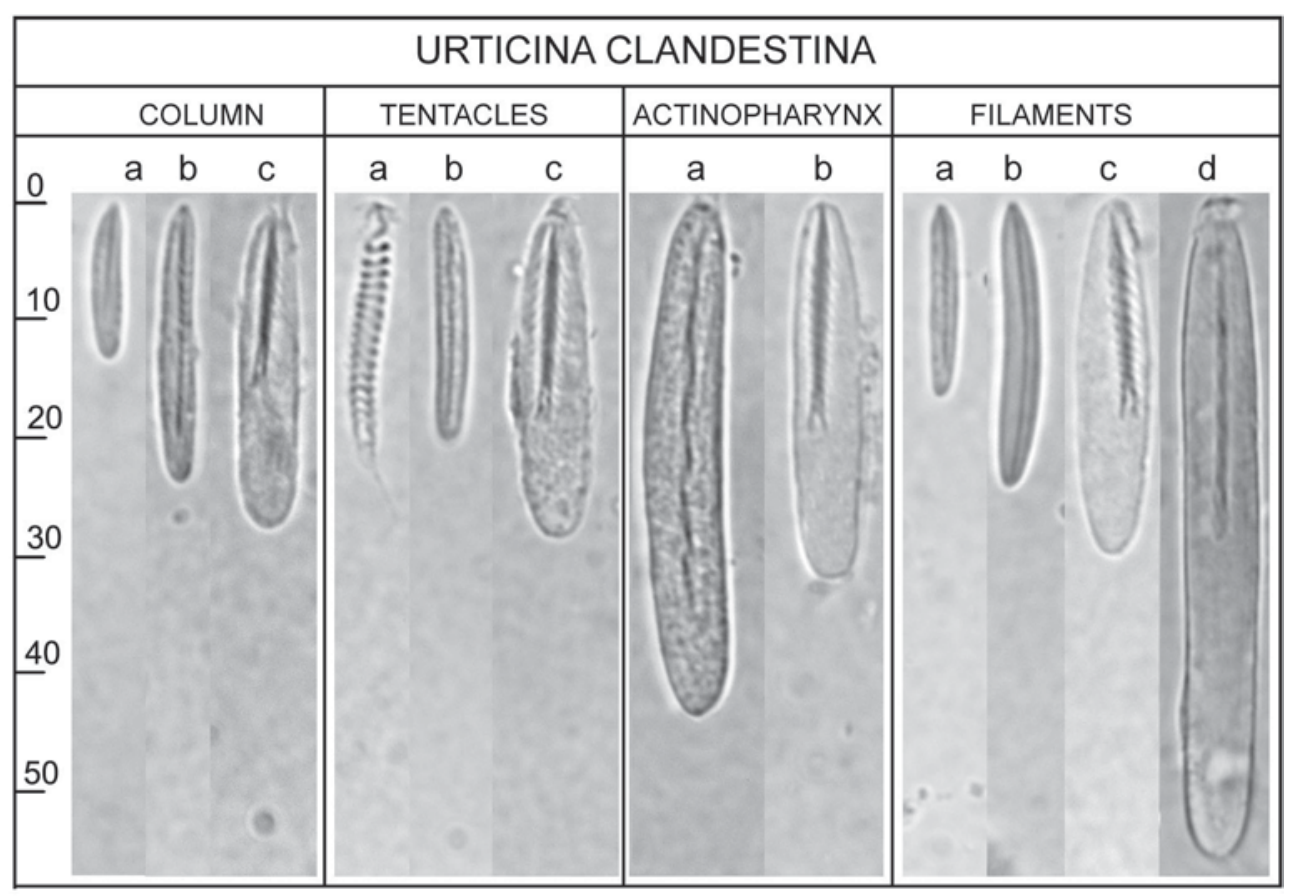

Fig. 4. Urticina clandestina sp.n., cnidom (see Table 1 for size ranges).

Pис. 4. Urticina clandestina sp.n., книдом (размерны указаны в табл. 1).

cies was observed from the low intertidal and shallow subtidal zone to $20 \mathrm{~m}$ deep.

ETYMOLOGY. Specific epithet refers to the "hidden" habit of this anemone being buried with only the oral disk exposed; "clandestina" in Latin is secret, hidden.

REMARKS. The present species has features characteristic of two closely related actiniid genera, Urticina and Cribrinopsis. The species belonging to these genera have several common features, including many morphological characters and details of cnidom, and obviously constitute a closely related group. They all are rather large, and most could be easily separated from other anemones even by underwater photographs due to their distinctive habitus and, especially, by decamerous arrangement of the tentacles. The two genera are distinguished by two main features: by the distribution of gonads (in Cribrinopsis all cycles of mesenteries may be fertile, while in Urticina the mesenteries of the first cycle are mostly sterile), and by differences in size ranges of nematocysts in the tentacles and actinopharynx (in Urticina basitrichs in the actinopharynx are larger than large ba- sitrichs in the tentacles, and size ranges do not overlap). Basitrichs in the actinopharynx of the present species are somewhat smaller than in other Urticina species, but otherwise the cnidom is similar and size ranges of large basitrichs in the actinopharynx and tentacles do not overlap - a feature characteristic for Urticina but not for Cribrinopsis. On the other hand, the present species has gonads on all mesenteries of the first cycle, a feature not reported before for Urticina but common for Cribrinopsis. Therefore the taxonomic position of the present species appears to be intermediate between these two genera. According to Sanamyan, Sanamyan (2006) the distribution of gonads is a rather ambiguous feature separating these genera. It is true that in most specimens of most species of Urticina the first cycle of mesenteries is sterile, but occasionally gonads may be present on some mesenteries of this cycle (Hand, 1955; Sanamyan, Sanamyan, 2006). Thus we assign the present species to Urticina rather than to Cribrinopsis.

The genus Urticina currently comprises seven valid species (U.felina (Linnaeus, 1761), $U$. 
crassicornis (Müller, 1776), U. eques (Gosse, 1860), U. fecunda (Verrill, 1899), U. kurila (Averincev, 1967), U. piscivora (Sebens et Laakso, 1987), U. grebelnyi Sanamyan and Sanamyan, 2006) and one species for which assignment to this genus needs confirmation $(U$. columbiana Verrill, 1922, see Sanamyan, Sanamyan, 2006). This list is not congruent with the current list of valid Urticina species in the database "Hexacorallians of the World" (Fautin, 2013), which contains a number of synonyms and is confusing - the same specimens may be assigned simultaneously to several species marked as valid (e.g. the holotype of Actinea tuberculata Cocks, 1851 is in the list of specimens for $U$. tuberculata, U. felina and U. coriacea).

Urticina clandestina sp.n. most closely resembles $U$. felina known from European seas. Both species live buried in gravel and are covered by numerous adhesive verrucae (although in $U$. felina they appear to be larger). The cnidom of $U$. felina differs from that of $U$. clandestina sp.n. In particular, large basitrichs in the actinopharynx are significantly larger than in $U$. clandestina sp.n. Urticina felina lacks p-mastigophores A in the actinopharynx which are common in the actinopharynx of $U$. clandestina sp.n. and also present in the column and tentacles; also large thick basitrichs are found in filaments of $U$. felina but are not present in $U$. clandestina sp.n. The differences of the cnidom are substantial enough to warrant non- conspecificity of the present species and $U$. felina. In addition, in most known specimens of $U$. felina the first cycle of mesenteries is sterile (Sanamyan, Sanamyan, 2006 recorded a gonad on one mesentery of one specimen of $U$. felina), while in the present species all mesenteries of the first cycle are fertile, a condition very different from that of $U$. felina.

Tealia coriacea: Hand, 1955 from California appears to be similar to the present species. Tealia coriacea (Cuvier, 1798) is a junior subjective synonym of $U$. felina, however Pacific specimens identified by Hand (1955) as T. coriacea are not conspecific with it (see Hartog, 1986; Sanamyan, Sanamyan, 2006). Size ranges of nematocysts reported by Hand (1955) for Californian species agree well with those of $U$. clandestina sp.n. although basitrichs in the actinopharynx may be larger and it has narrow Sshaped basitrichs in filaments which are not present in U. clandestina sp.n. The colour model of the disk and tentacles described by Hand (1955) agrees in part with our species, although the range of variation in Hand's species is wider. Hand (1955: 78) states that "gonads usually absent from the first 10 pairs" of mesenteries. The word "usually" implies that gonads sometimes may present on the mesenteries of the first cycle, but in general the condition described by Hand (1955) differs from that in U. clandestina sp.n. in which all these mesenteries have well developed gonads.

The only other decamerous Urticina species possessing strongly adhesive verrucae and living buried in gravel is U. kurila (Averincev, 1967), described from the Kurile Islands (NW Pacific) and known only from the original description. Basitrichs in the actinopharynx of this species are two times larger than those of $U$. clandestina sp.n. and p-mastigophores B1 in the filaments are smaller. According to the original description the first cycle of the mesenteries of this species is usually sterile and the colour model of the oral disk is very different (see Sanamyan et al., 2013).

Cribrinopsis olegi Sanamyan, Sanamyan, 2006 resembles Urticina clandestina sp.n. in its buried habit and short decamerously arranged tentacles, although usually the colour and the shape of the tentacles (more ampullaceous) differs clearly in living specimens. This species was originally described from the NW Pacific, but later reported from the White Sea (Sanamyan, Sanamyan, 2009, 2010). Its range probably extends to the NE Pacific (at our disposal is a photograph certainly showing this species taken by Dr. John Butler at $100 \mathrm{~m}$ off California coast, $32.611^{\circ} \mathrm{N}, 119.323^{\circ} \mathrm{W}$, see Sanamyan et al., 2013). It has a cnidom typical for Cribrinopsis and thus could be easily distinguished from the present species even in preserved condition, when the most eye-catching differences in the colour model of the disk and tentacles and the shape of the tentacles disappear.

\section{Aulactinia vancouverensis sp.n. \\ Table 2; Figs. 5-8.}

MATERIAL EXAMINED. Holotype: ZIN No. 11329, according to the incoming catalog at the Sponges and Coelenterates Department of ZIN RAS, British Columbia, Canada: Kuldekduma Island, $50^{\circ} 35.281^{\prime} \mathrm{N}, 126^{\circ} 50.016^{\prime} \mathrm{W}$, $5 \mathrm{~m}$, March 22 2010, collector N. McDaniel and D. 
Swanston. Paratypes: KBPGI 417/1 (+), 418/2 (+), 419/3 $\left(O^{7}\right)$, same locality, three specimens.

DESCRIPTION. External structure. The specimens are of medium size, living specimens with a column generally less than $4 \mathrm{~cm}$ in diameter and usually less than $7 \mathrm{~cm}$ in length. The tentacular crown of fully expanded specimens is usually not more than $8 \mathrm{~cm}$ in diameter. Formalin-preserved specimens are from 21 to $37 \mathrm{~mm}$ in height. The diameter of the circular and strongly adhesive pedal disk is usually somewhat larger than the diameter of the middle part of column (Fig. 5F). The column is almost cylindrical or somewhat narrower in the middle. The oral disk is of about the same diameter as pedal disk or somewhat smaller. The column has numerous small (but clearly visible on living specimens) verrucae arranged regularly in distinct vertical rows over each endocoel. The rows of verrucae run from the margin along the whole length of column and disappear only just above the limbus. Most verrucae are of similar size, only several most proximal and distal verrucae in a row may be somewhat smaller than the rest. Verrucae are weakly adhesive with sparse particles of gravel or broken shells attached to them (Fig. 5D, E) or the column may be bare, without attached particles (Fig. 5F). On preserved specimens verrucae are poorly discernible (Fig. 5A). There is a deep (up to $3 \mathrm{~mm}$ ) fosse. There are no special marginal structures.

The oral disk is circular and almost flat, the area around the mouth may be somewhat raised. The tentacles, up to about 100 in number, are arranged hexamerously on the outer part of the oral disk usually in five cycles, with occasional additional tentacles belonging to the sixth cycle. The tentacles are typical for this group of sea anemones appearance, smooth, without any wrinkles (in living specimens), tapering, the length of the tentacles usually not exceeding the diameter of oral disk (Fig. 5C).

The column, tentacles, and oral disk of living specimens are plain bright pink, or occasionally the tentacles may be somewhat paler than the column and the disk. The verrucae are whitish. Insertions of mesenteries on the oral disk are visible as somewhat darker faint radial lines. Actinopharynx is whitish. The overall pink colour of living specimens is very consistent and diagnostic.

Internal structure. Marginal endodermal sphincter muscle is strong, about $1.5-2 \times 1 \mathrm{~mm}$ on transverse section, circumscribed, oval, pinnate, with usually well defined central lamella attached to body wall near the bottom of the fosse. Typically the sphincter is almost symmetrical with muscle processes on opposite sides of central lamella of more or less equal length (Fig.6 A, B), but occasionally in some parts of the same specimen muscle processes on one side of central lamella may be strongly reduced producing an asymmetrical appearance of the sphincter on cross section (Fig. 7A). Longitudinal muscles of the tentacles and radial muscles of oral disk are ectodermal (Fig. 6D). Circular endodermal columnar muscles well developed on the whole column but absent on the tops of verrucae. Verrucae have thin mesogloea in the centre and modified ectoderm composed of densely packed epitheliomuscular cells and lack nematocysts and glandular cells. Ectoderm of verrucae stains deeper with acid dyes than the ectoderm of the rest of column wall (Fig. 6A). Actinopharynx has two deep siphonoglyphs supported by directives.

The mesenteries are arranged hexamerously in four cycles: $6+6+12+24$ with addition of several pairs of small mesenteries belonging to the fifth cycle. The length of the mesenteries of the first and the second cycles on transverse sections is similar. The number of mesenteries is the same along the whole length of column. Mesenteries of first, second and third cycles are perfect. Mesenteries have large elongated oral stomata (up to $5 \mathrm{~mm}$ in length) and small marginal stomata (about $0.5 \mathrm{~mm}$ diameter). Retractor muscles are diffuse, long on mesenteries of first to third cycles and more or less restricted on mesenteries of fourth cycle. Muscle processes are numerous, short and heavily branched (Fig. 6C). Parietobasilar muscles are well developed with short or long free flap. Basilar muscles are well developed.

Mesenteries of all cycles (from first to fifth) are fertile. On the first two cycles of mesenteries gonads are situated proximally (closer to the pedal disk), on younger cycles gonads are situated more distally. Sexes are separate. The diameter of the eggs is $0.5-1 \mathrm{~mm}$. Embryos of about $1-2 \mathrm{~mm}$ in diameter are present in the coelenteron. The smallest of them either lack tentacles, or already have six very small tentacles, the larger ones may have 12 tentacles and two cycles of mesenteries, six pairs of which are 
Table 2. Size ranges (length $\mathrm{x}$ width, in microns) and distribution of cnidae of Aulactinia vancouverensis sp.n. Letters in brackets correspond to letters in Fig. 8. "N" — ratio of number of specimens in which each cnidae was found to number of specimens examined.

Таблица 2. Размеры (длина х ширина, в микронах) и распределение стрекательных капсул Aulactinia vancouverensis sp.n. Буквы в скобках соответствуют буквам на рис. 8. "N" — отношение количества экземпляров, в которых данный тип книд был найден, к количеству исследованных экземпляров.

\begin{tabular}{|l|l|c|c|}
\hline Body region & \multicolumn{1}{|c|}{ Cnidae } & Size ranges $(\mu \mathrm{m})$ & $\mathrm{N}$ \\
\hline Column (ectoderm) & (a) basitrichs (rare) & $6-11 \times 1-2$ & $3 / 3$ \\
\hline & (b) basitrichs (common) & $17-29 \times 2-3$ & $3 / 3$ \\
\hline Column (endoderm) & (a) basitrichs (very rare) & $10-16 \times 1.5-2.5$ & $2 / 2$ \\
\hline & (b) S-basitrichs (very rare) & $26-38 \times 1-2$ & $2 / 2$ \\
\hline & (a) spirocysts (very rare) & $23-30 \times 2.5-3.5$ & $3 / 3$ \\
\hline & (b) basitrichs (rare) & $6-9 \times 1-2$ & $3 / 3$ \\
\hline & (c) basitrichs (very numerous) & $17-25 \times 2-3$ & $3 / 3$ \\
\hline & (d) p-mastigophores A (rare) & $22-30 \times 4-6$ & $3 / 3$ \\
\hline & (a) holotrichs (numerous) & $25-37 \times 3.5-5$ & $4 / 4$ \\
\hline & (b) basitrichs (rare) & $6-10 \times 1-2$ & $4 / 4$ \\
\hline & (c) basitrichs (numerous) & $17-30 \times 2-3$ & $4 / 4$ \\
\hline & (a) spirocysts (very numerous) & $16-42 \times 1.5-3.5$ & $3 / 3$ \\
\hline & (b) holotrichs (see text) & $21-30 \times 3-5$ & $3 / 3$ \\
\hline & (c) basitrichs (common) & $22-35 \times 2-3$ & $3 / 3$ \\
\hline Actinopharynx & (a) basitrichs (numerous) & $25-43 \times 4.5-6$ & $3 / 3$ \\
\hline & (b) p-mastigophores A (rare) & $13-21 \times 2-2.5$ & $4 / 4$ \\
\hline Filaments & (a) basitrichs (common) & $36-47 \times 4-5.5$ & $4 / 4$ \\
\hline & (b) basitrichs (numerous) & $23-31 \times 4-5.5$ & $4 / 4$ \\
\hline & (c) p-mastigophores A (common) & $25-39 \times 5-7$ & $4 / 4$ \\
\hline & (d) p-mastigophores B1 (few) & & $3 / 3$ \\
\hline
\end{tabular}

perfect and six others are very small. Smaller and larger embryos are present in the same parent specimen simultaneously.

Cnidom. Spirocysts, holotrichs, basitrichs, p-mastigophores A and p-mastigophores B1 (see Fig. 8 and Table 2 for size ranges and distribution). The interesting feature is the presence of numerous basitrichs in the ectoderm of the fosse. These basitrichs are not confined to any special structures (like pseudospherules), but line the whole surface of the fosse from parapet to about the level where circumscribed sphincter is attached, forming a sort of "basitrichs pad" (Fig. 7B). The basitrichs are especially numerous in the upper (closer to parapet) and middle parts of the fosse, where they sometimes form a layer with the numerous capsules set close to each other. They become less numerous toward the bottom of the fosse where they disappear completely.
Holotrichs are numerous on the limbus. They are confined to a very limited area forming a narrow band running along the limbus, but not present on the scapus just above the limbus and on the pedal disk below the limbus. In this narrow band also present numerous basitrichs. In the tentacles holotrichs are present on the tips of outer tentacles only where basitrichs also become rather numerous. On the pedal disk the same two types of basitrichs are present as on the main part of column, but they are more sparse.

Endoderm of column and pedal disk contains very sparse narrow S-basitrichs and small basitrichs which could be revealed on thicker $(8-10 \mu \mathrm{m})$ histological sections stained by basic dyes, but hard to detect on usual squash preparations of endoderm where we were able to find only several sparse capsules.

Cnidoglandular tracts of filaments contain four types of nematocysts (see Table 2), while the 

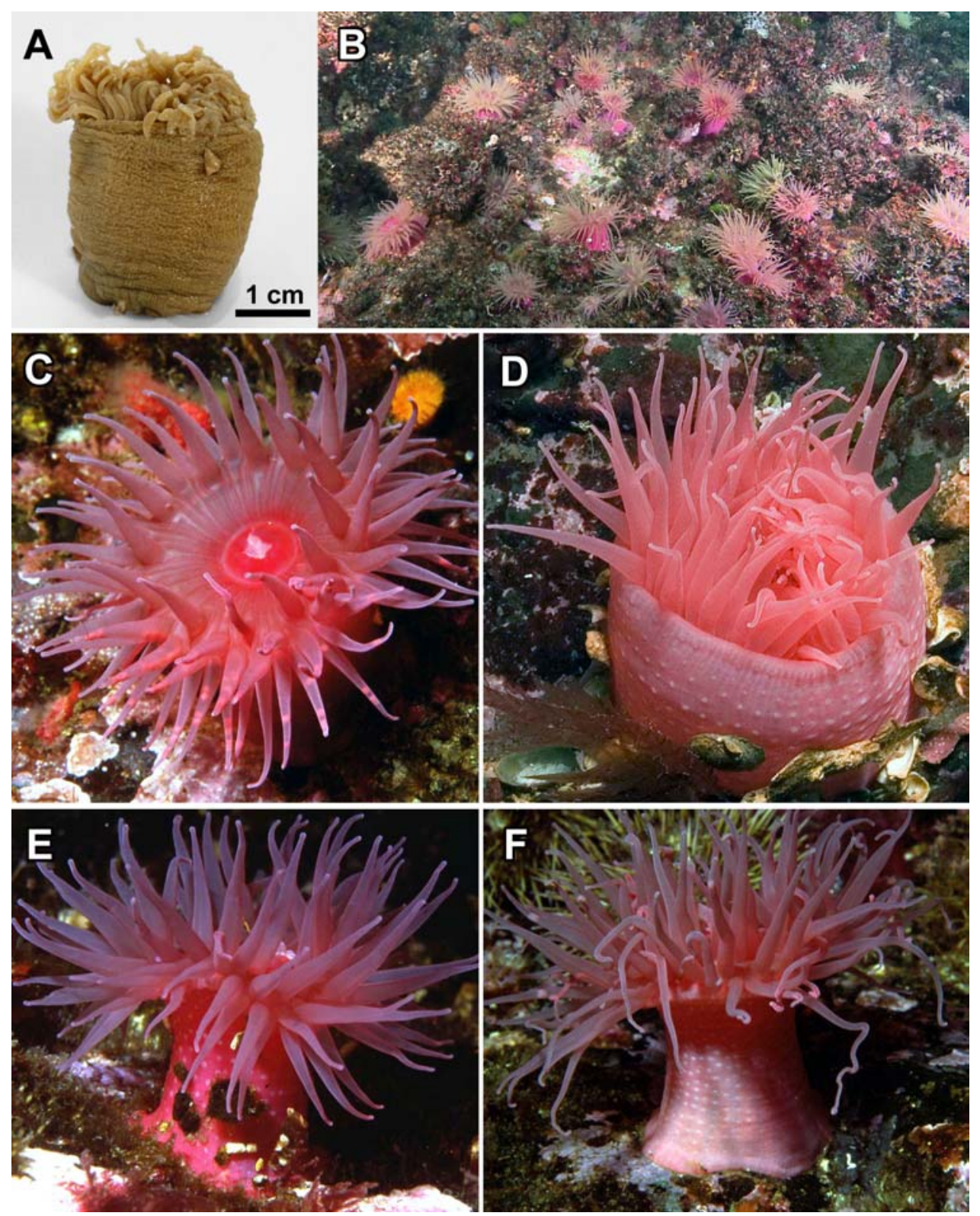

Fig. 5. Aulactinia vancouverensis sp.n., external appearance.

A - holotype, preserved, side view; B - a frame from videotape showing numerous specimens at the Masterman Islands near northern Vancouver Island; $\mathrm{C}$ - oral disk and tentacles of expanded specimen, note embryos in the tentacles; D partially contracted specimen, note almost smooth margin and appearance of verrucae; E - side view of expanded specimen, note foreign particles attached to column; F - side view of specimen with bare column, note regular arrangement of whitish verrucae.

Рис. 5. Aulactinia vancouverensis sp.n., внешний вид.

А — голотип, фиксированный, вид сбоку; В — кадр с видеопленки, показывающий многочисленные экземпляры у о. Мастерман около северной части о. Ванкувер; $\mathrm{C}$ - оральный диск и щупальца расправленного экземпляра, видны эмбрионы в щупальцах; D - частично сокращенный экземпляр, хорошо видны верруки и практически гладкий маргин; E - вид сбоку на расправленный экземпляр, видны посторонние частицы, прикрепленные к колюмну; F — вид сбоку на экземпляр с чистым колюмном, видно регулярное расположение беловатых веррук. 


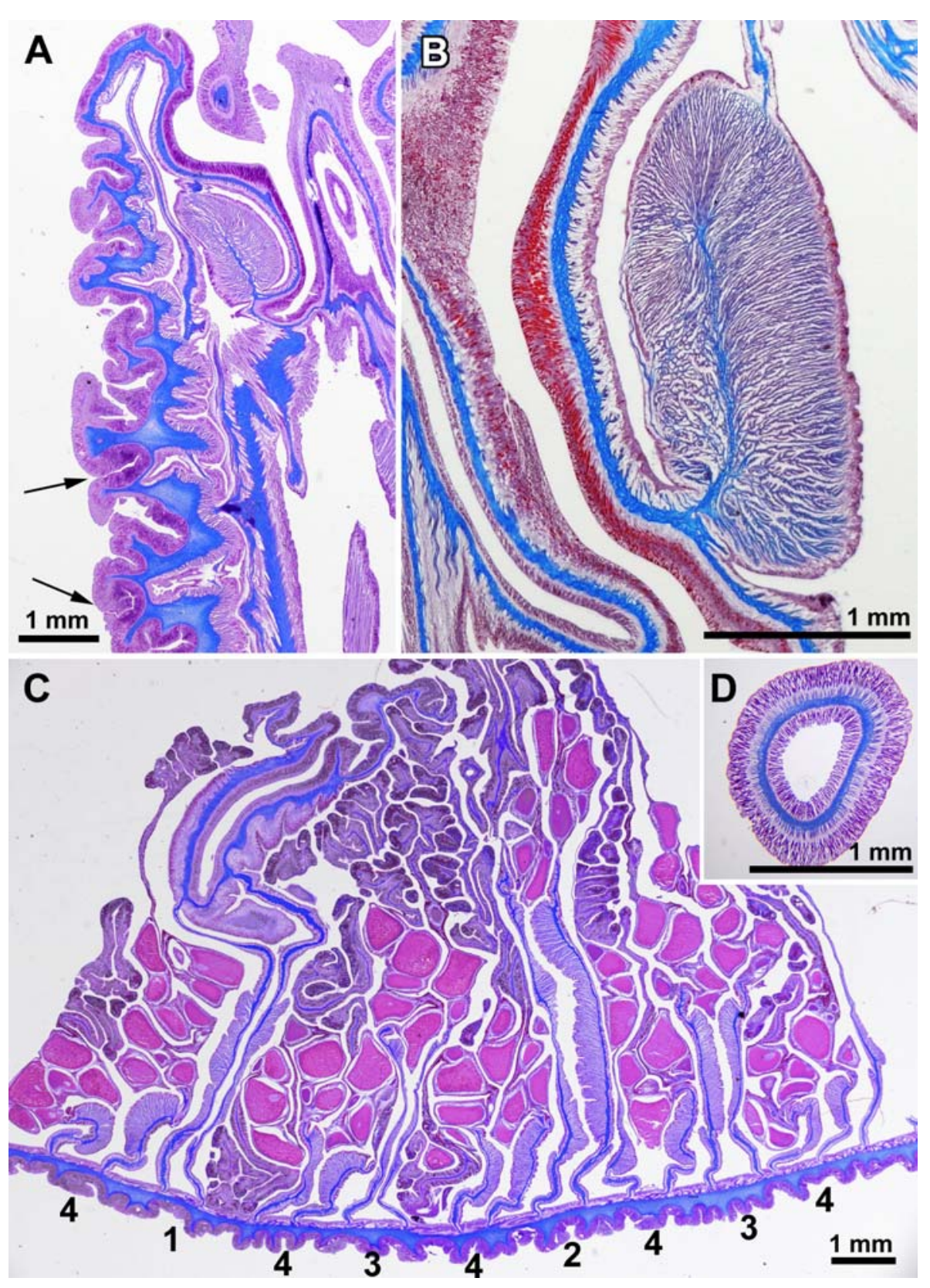

Fig. 6. Aulactinia vancouverensis sp.n., cross sections.

A - longitudinal section through distal column (specimen KBPGI 417/1) showing verrucae on column (arrows), deep fosse and circumscribed marginal sphincter; B - marginal sphincter of another specimen (KBPGI 418/2), enlarged; $\mathrm{C}$ - transverse section through the column (specimen KBPGI 417/1), cycles of mesenteries are marked by numbers; D - transverse section through the tentacle (specimen KBPGI 417/1).

Рис. 6. Aulactinia vancouverensis sp.n., гистологические срезы.

А - продольный срез через дистальную часть колюмна (экземпляр KBPGI 417/1), видны верруки на колюмне (стрелки), глубокая фосса и циркумскриптический маргинальный сфинктер; В - маргинальный сфинктер другого экземпляра (KBPGI 418/2), увеличено; C — поперечный срез через колюмн (экземпляр KBPGI 417/1), циклы мезентериев отмечены цифрами; D - поперечный срез через щупальце (экземпляр КBPGI 417/1). 

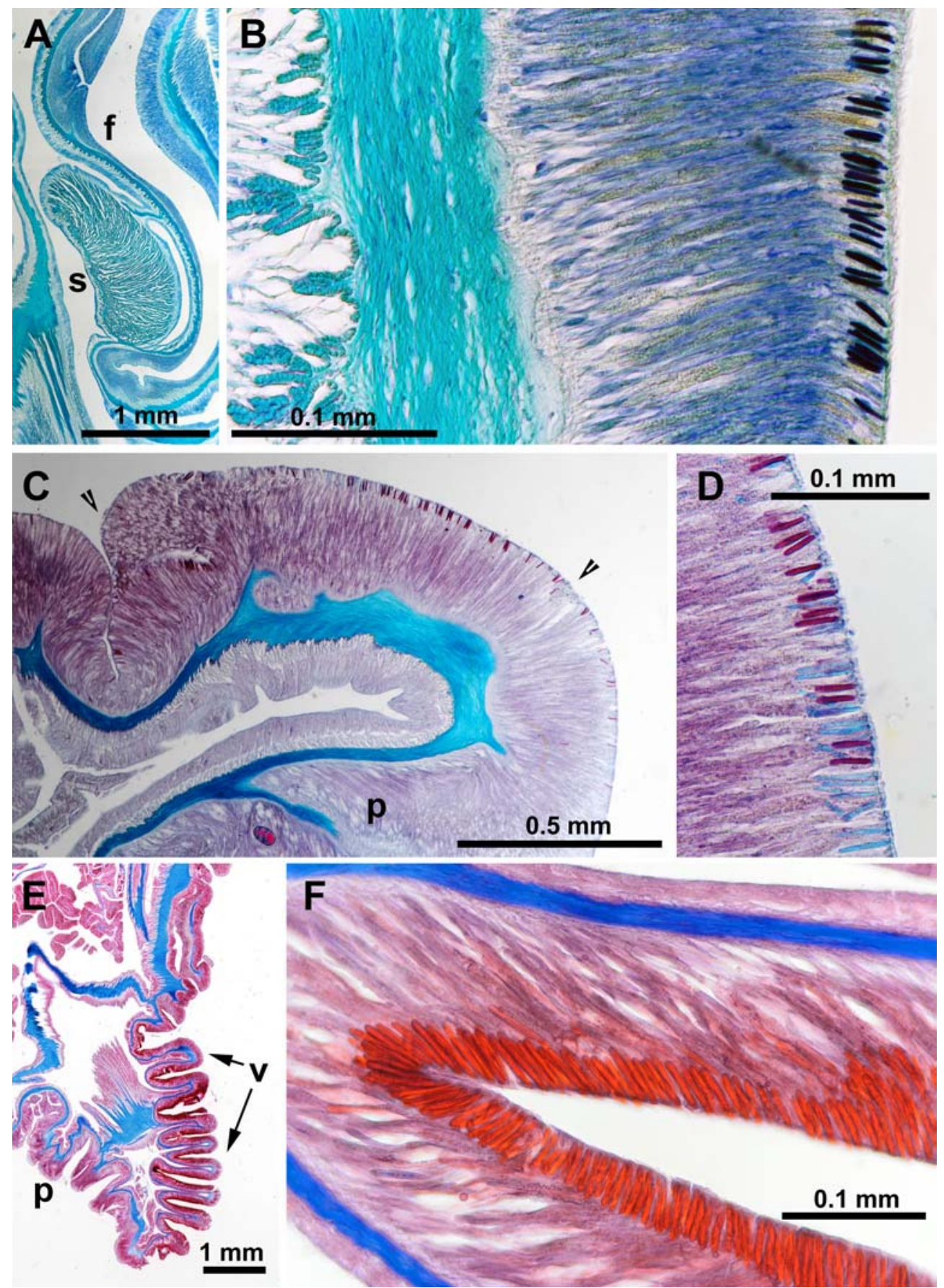

Fig. 7. Aulactinia vancouverensis sp.n. (A-D) and Cnidopus japonicus (E-F), cross sections.

A - longitudinal section through fosse and circumscribed marginal sphincter of specimen KBPGI 417/1, note asymmetrical marginal sphincter on this slide; B - numerous basitrichs (stained almost black by Toluidine blue) lining the fosse; $\mathrm{C}$ - longitudinal section through the limbus, note a narrow region with numerous deeply stained basitrichs (arrows mark area near the limbus where holotrichs occur); D - the same region, enlarged, note deeply stained basitrichs and numerous pale (stained in the same blue-green colour as the mesogloea) holotrichs; E - longitudinal section of 
digestive region of filaments contains only smaller basitrich, and, sometimes, large basitrichs of the same types as in cnidoglandular tract.

HABITAT AND DISTRIBUTION. The species is usually found attached to small rocks or bedrock with an upright column. Some specimens are found in crevices and partly covered by attached gravel particles, and sometimes the lower part of column may be buried in shell hash. This species is not widespread along the British Columbia coast. It is most abundant in shallow water in Weynton Passage at the north end of Johnstone Strait, which lies between Vancouver Island and the mainland of British Columbia. It has not been observed within the Strait of Georgia. Typically the species is found in shallow water at depths not exceeding $5 \mathrm{~m}$, but occasional specimens were recorded to depths of $25 \mathrm{~m}$.

ETYMOLOGY. The species is named after the locality near northern Vancouver Island.

REMARKS. Generic assignment. The species belongs to a large (and rather difficult from taxonomic point of view) group of species formerly united under the generic name Bunodactis Verrill, 1899. Dunn et al. (1980) replaced this name by its older subjective synonym Aulactinia Verrill, 1864. England (1987, 1992) proposed to remove from Aulactinia all species having marginal spherules (including Bunodactis verrucosa (Pennant, 1777), the type species of Bunodactis) and place them to Gyractis Boveri, 1893. However, the name Bunodactis is still used in some recent publications (e.g. Ocaña, Hartog, 2002; Hartog, Ates, 2011). According to Dr. M. Daly (Ohio State University, USA) (2008, personal comm.) the type species of Aulactinia (A. capitata Agassiz in Verrill, 1864) is not congeneric with the type species of Bunodactis. Obviously, the whole group needs a revision before accurate generic assignment of included species could be assessed. Pending such a revision we, in the present paper, treat Aulactinia as a valid generic name for the species described here. Since the present species has no marginal projections its assignment to Aulactinia is in agreement with the definitions of the genus proposed by Dunn et al. (1980) as well as with a more restricted understanding of this genus as proposed by England $(1987,1992)$.

Comparison with related species. Two internally brooding Aulactinia species were recorded previously from the North Pacific. The first species, A. incubans Dunn, Chia et Levine, 1980 was originally described from the NE Pacific. The type locality of $A$. incubans, where it is rather common (Dunn et al., 1980 based their descriptions on more than 500 living specimens), San Juan Island, is about $350 \mathrm{~km} \mathrm{SE} \mathrm{of}$ Kuldekduma Island, the type locality of Aulactinia vancouverensis sp.n. Aulactinia incubans is easily distinguished from the present species by characteristic white radial lines running on the oral disk from just beyond oral cone to the bases of tentacles, except two lines over directive endocoels which originate on siphonoglyphs and cross the oral cone (Dunn et al., 1980). Aulactinia vancouverensis sp.n. has a plainly coloured oral disk, without any white lines or markings. The cnidom reported in the original description of $A$. incubans resembles the cnidom of $A$. vancouverensis sp.n. in the composition of cnidae in studied regions of the body, except for the presence of small basitrichs in the actinopharynx of $A$. incubans which are not

proximal part of column (including the limbus and the base) of Cnidopus japonicus, note crowded vesicles with thin mesogloea and a rather smooth wall of column above the zone of vesicles where mesogloea is much thicker; $\mathrm{F}$ - enlarged area between two vesicles of the same specimen to show nematocyst battery consisting of extraordinary numerous holotrichs (stained red by Safranin).

Abbreviations: f — fosse; $\mathrm{p}$ - pedal disk; s — marginal sphincter; v — vesicles.

Рис. 7. Aulactinia vancouverensis sp.n. (А-D) и Cnidopus japonicus (Е-F), гистологические срезы.

A - продольный срез через фоссу и циркумскриптический маргинальный сфинктер экземпляра KBPGI 417/1, на этом срезе сфинктер асимметричен; В - многочисленные базитрихи (окрашены почти в черный цвет толуидиновым синим), выстилающие фоссу; С - продольный срез через лимбус, видна узкая область с многочисленными глубоко окрашенными базитрихами (стрелки показывают границы области около лимбуса, где встречаются голотрихи); D - тот же участок, увеличено, видны сильноокрашенные базитрихи и светлые (окрашенные так же, как и мезоглея) голотрихи; Е - продольный срез через проксимальную часть колюмна (включая лимбус и педальный диск) Cnidopus japonicus, видны многочисленные везикулы с тонкой мезоглеей и довольно гладкая стенка колюмна выше зоны везикул, где мезоглея значительно толще; F — область между двумя везикулами того же экземпляра, увеличено, видна батарея нематоцист из многочисленных голотрихов (окрашены в красный цвет сафранином).

Сокращения: f — фосса; p — педальный диск; s — маргинальный сфинктер; v — везикулы. 
present in A. vancouverensis sp.n. However, basitrichs in the tentacles and actinopharynx of $A$. vancouverensis sp.n. are larger than those of $A$. incubans. P-mastigophores A in actinopharynx of $A$. vancouverensis sp.n. are also larger than pmastigophores of actinopharynx in A. incubans and their size ranges do not overlap. Basitrichs of the column and spirocysts of tentacles also could attain larger size in A. vancouverensis sp.n.

Another internally brooding shallow-water species of Aulactinia reported from the N Pacific is A. stella (Verrill, 1864). Carlgren (1934) reported it from Unalaska and Sanamyan, Sanamyan $(1998,2009,2010)$ from the Commander Islands and East Kamchatka. It is not quite clear if these N Pacific specimens are indeed conspecific with Verrill's A. stella (originally described from Atlantic coast of $\mathrm{N}$ America) but at least smaller, paler specimens of this species are not distinguishable from the specimens from European locations (in particular from the specimens from White Sea and Barents Sea) which traditionally (since Carlgren, 1921) are identified as A. stella. This species is mostly found buried in gravel up to the level of its tentacles, has stronger verrucae than those of $A$. vancouverensis sp.n. (visible not only on living, but also on preserved specimens), white radial lines on the disk (identical to those of $A$. incubans) and also differs from $A$. vancouverensis sp.n. by the size ranges of its nematocysts, which are similar to those reported by Dunn et al. (1980) for A. incubans and smaller than in $A$. vancouverensis sp.n. Also, basitrichs in fosse are significantly sparser.

Aulactinia sinensis Li et Liu, 2012 recently described from the Yellow Sea (W Pacific) differs distinctly from $A$. vancouverensis sp.n. by many features including the presence of zooxantellae in its tissues. According to Li and Liu (2012) holotrichs in this species are present in all examined tissues (tentacles, column, actinopharynx, filaments).

Columnar holotrichs. Columnar holotrichs, forming a narrow band running along the limbus are a rather interesting feature. They are present in the same position (only at limbus) in N Pacific specimens of $A$. stella we examined. Rare holotrichs in the lower part of column were reported in Epiactis prolifera Verrill, 1869 (type species of Epiactis) by Fautin and Chia (1986), who measured two capsules in one (of seven examined) specimen. They also recorded few holot- richs in the outer tentacles in some specimens of E. prolifera, E. lisbethae Fautin et Chia, 1986, and $E$. fernaldi Fautin et Chia, 1986. According to these authors holotrichs seem inducible and systematic weight cannot be attributed to their presence or absence. However, seemingly sporadic occurrence of holotrichs in some species might be connected with their patchy or local distribution along the length of the column or tentacles. As revealed by the present study they may be numerous at the limbus, but totally absent in other parts of the column and thus might be easily overlooked if distribution of nematocysts is studied on smears only. Columnar holotrichs probably have wider occurrence in actiniid species and of course, their presence or absence, if correctly observed and analyzed in combination with other features, has certain systematic weight.

Presence of a narrow band of holotrichs at the limbus in A. vancouverensis sp.n., A. stella as well as their sporadic occurrence in E. prolifera should not be confused with the condition seen in the genus Cnidopus. In Cnidopus japonicus (Verrill, 1869) (senior subjective synonym of the type species of the genus, see Sanamyan, Sanamyan, 1998) holotrichs are confined to and are extraordinarily numerous on the sides of crowded, hollow, thin-walled vesicles arranged in several transverse rows on the most proximal part of column (Fig. 7E). In A. vancouverensis sp.n. holotrichs are not confined to any special structures and do not form such strong nematocyst batteries (area with very numerous nematocysts standing very close to each other) as in Cnidopus. It is interesting to note that we failed to stain holotrichs of $A$. vancouverensis sp.n. and $A$. stella by basic dyes in the same way as they stain in C. japonicus, and on microscopic slides (Fig. 7D) they appear very pale in contrast with deeply stained basitrichs. At the same time holotrichs of sectioned specimen of C. japonicus (KBPGI 414/43) are stained easily and deeply by basic dyes (Fig. 7F). This may reflect chemical differences in these nematocysts.

Carlgren (1950a, b) reported and figured vesicles covered on the sides (but not on the tips) with "extraordinarily numerous nematocysts as in the marginal spherules" in the lower part of a column in a species he identified as Cnidopus verater (Drayton in Dana, 1846). These vesicles with batteries of holotrichs ap- 


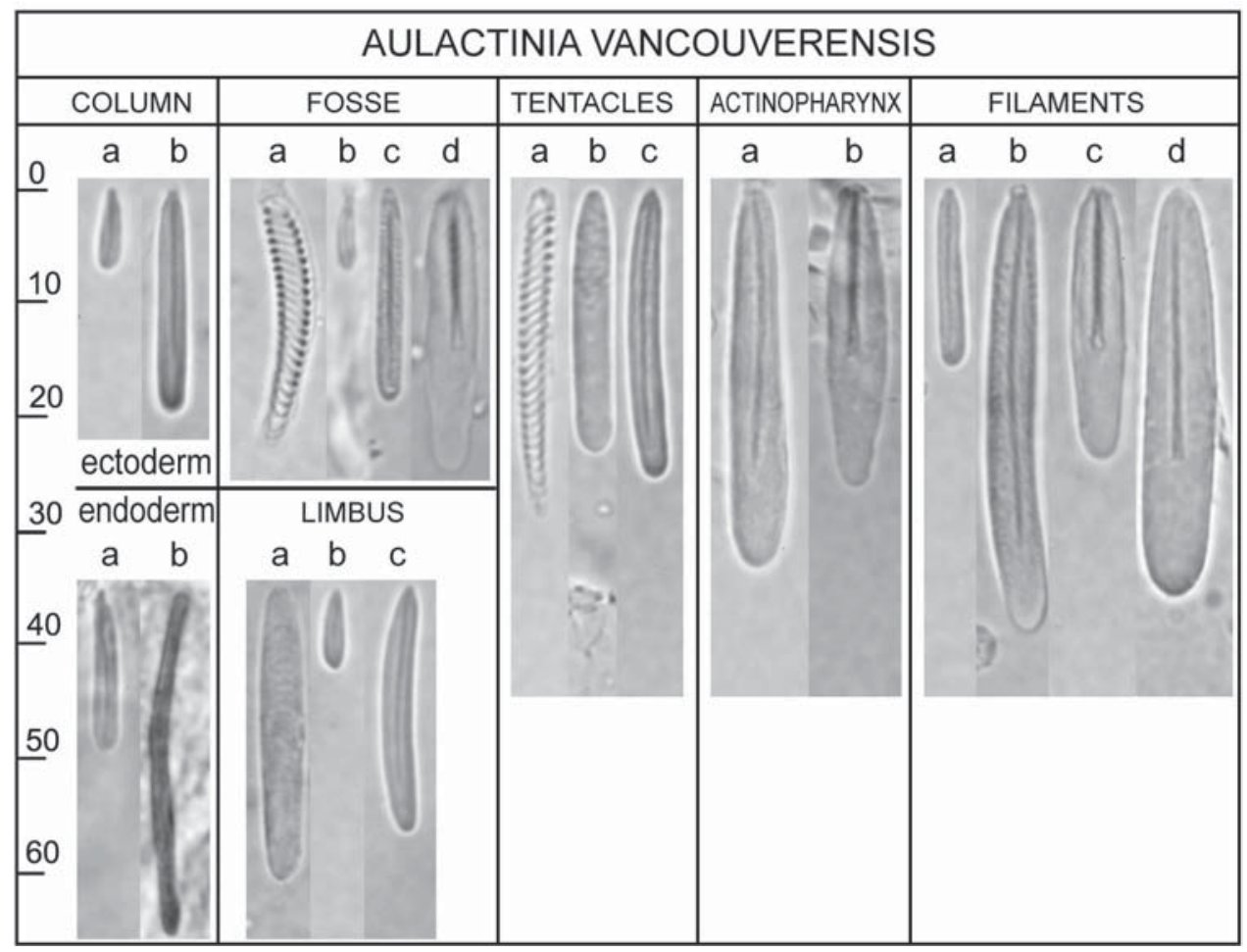

Fig. 8. Aulactinia vancouverensis sp.n., cnidom (see Table 2 for size ranges).

Рис. 8. Aulactinia vancouverensis sp.n., книдом (размеры указаны в табл. 2).

pear very similar to those in $C$. japonicus. Edmands and Fautin (1991) redescribed this species based on newly collected specimens and moved it to Aulactinia (as A. veratra). Unfortunately from the description they provide it is not clear if the species examined had vesicles in the lower part of the column with extraordinarily numerous holotrichs, as described by Carlgren (1950a). Actually holotrichs were not present in all specimens they examined and were probably rather sparse. If so, Aulactinia veratra described by Edmands and Fautin (1991) indeed may be a member of the genus Aulactinia, but probably not conspecific with the species described by Carlgren (1950a) as Cnidopus verater.

The cnidae usually termed "holotrichs" are also found in the column of many actiniid species possessing acrorhagi, for example in many Anthopleura species. According to Hartog (1987: 556) the "homotrichs" (the term he used for holotrichs and heterotrichs) "seem to occur especially, though not invariably, in species possessing acrorhagi". However, England (1987: 239) warned that cnidae occurring in the column of Anthopleura (which he termed "heterotrichs") "should not be confused with atrichs [=holotrichs in the present paper] that occur only at limbus in certain anemones, but usually in large numbers".

Holotrichs in tentacles. Holotrichs present in the tips of outer tentacles may indicate that the species may develop fighting tentacles (also termed "catch-tentacles"). In endomyarian anemones fighting tentacles with extraordinarily numerous holotrichs are known only in $\mathrm{Cni}$ dopus japonicus and in Pacific specimens of Aulactinia stella (see Sanamyan, Sanamyan, 1998, 2009, 2010). In these two species we observed fighting tentacles in living specimens in their natural habitat, and long fighting tentacles are often developed in specimens kept in aquaria. Holotrichs in tentacles (including fighting tentacles) do not stain by basic dyes in these species. Unlike mesomyarian anemones (e.g. Metridium, Diadumene) where fighting tentacles are developed from the tentacles of inner cycle, in Cnidopus and Aulactinia they are developed from the tentacles of outer cycle. 


\section{References}

Buessa R.J., Peshkov M.V. 2009. Histology without xylene // Annals of Diagnostic Pathology. Vol.13. P.246-256.

Carlgren O. 1921. Actiniaria Part $1 / /$ The Danish Ingolf Expedition Vol.5. No.9. P.1-241.

Carlgren O. 1934. Some actiniaria from Bering Sea and Arctic waters // Journal of the Washington Academy of Sciences. Vol.24. No.8. P.348-353.

Carlgren O. 1949. A survey of the Ptychodactiaria, Corallimorpharia and Actiniaria // Kungliga Svenska Vetenskapsakademiens Handlingar. Vol.1. P.1-121.

Carlgren O. 1950a. Corallimorpharia, Actiniaria and Zoantharia from New South Wales and South Queensland // Arkiv för zoologi. Bd.1. H.10. S.131-146.

Carlgren O. 1950b. Actiniaria and Zoantharia from South Australia // Kungl Fysiografiska Sällskapets I Lund Förhandlingar. Bd.20. Nr.10. S.1-15.

Dunn D.F., Chia F., Levine R. 1980. Nomenclature of Aulactinia (=Bunodactis), with description of Aulactinia incubans sp.n. (Coelenterata: Actiniaria), an internally brooding sea anemone from Puget Sound / / Canadian Journal of Zoology. Vol.58. P.2071-2080.

Edmands S., Fautin D.G. 1991. Redescription of Aulactinia veratra n.comb. (=Cnidopus veratra) (Coelenterata: Actiniaria) from Australia // Records of the Western Australian Museum. Vol.15. No.1. P.59-68.

England K.W. 1987. Certain Actiniaria (Cnidaria, Anthozoa) from the Red Sea and tropical Indo-Pacific Ocean // Bulletin of the British Museum (Natural History). Zoology. Vol.53. No.4. P.205-292.

England K.W. 1992. Actiniaria (Cnidaria: Anthozoa) from Hong Kong with additional data on similar species from Aden, Bahrain and Singapore // B. Morton (ed.). Proceedings of the Fourth International Marine Biological Workshop: The Marine Flora and Fauna of Hong Kong and the Southern China. Hong Kong, 11-29 April 1989. Hong Kong: Hong Kong University Press. P.49-95.

Fautin D.G. 2013. Hexacorallians of the World. Available from: http://geoportal.kgs.ku.edu/hexacoral/anemone2/index.cfm

Fautin D.G., Chia F.S. 1986. Revision of sea anemone genus Epiactis (Coelenterata: Actiniaria) on the Pacific coast of North America, with descriptions of two new brooding species // Canadian Journal of Zoology. Vol.64. P.1665-1674.

Hand C. 1954. The sea anemones of Central California, Part 1. The Corallimorpharian and Athenarian anemones // Wasmann journal of biology. Vol.12. No.3. P.345-375.

Hand C. 1955. The sea anemones of Central California, Part 2. The Endomyarian and Mesomyarian anemones // Wasmann journal of biology Vol.13. No.1. P.37-99.

Hartog J.C. den. 1986. The Queen Scallop, Chlamys opercularis (L., 1758) (Bivalvia, Pectinidae), as a food item of the sea anemone Urticina eques (Gosse, 1860) (Actiniaria, Actiniidae) // Basteria. Vol.50. P.87-92.

Hartog J.C. den. 1987. A redescription of the sea anemone Bunodosoma biscayensis (Fisher, 1874) (Actiniaria, Actiniidae) // Zoologische Mededelingen, Leiden. Vol.61. No.36. P.533-559.

Hartog J.C. den. 1995. The genus Telmatactis Gravier, 1916 (Actiniaria: Isophellidae) in Greece and the eastern Mediterranean // Zoologische Mededelingen, Leiden. Vol.69. No.14. P.153-176.

Hartog J.C. den., Ates R.M.L. 2011. Actiniaria from Ria de Arosa, Galicia, northwestern Spain, in the Netherlands
Centre for Biodiversity Naturalis, Leiden // Zoologische Mededelingen, Leiden. Vol.85. No.2. P.11-53.

Li Y., Liu J.Y. 2012. Aulactinia sinensis, a new species of sea anemone (Cnidaria: Anthozoa: Actiniaria) from Yellow Sea // Zootaxa. Vol.3476. P.62-68.

Llewellyn B.D. 2013. StainsFile. The Internet Resource for Histotechnologists. Available from: http:// www.stainsfile.info.

Ocaña O., Hartog J.C. den. 2002. A catalogue of Actiniaria and Corallimorpharia from the Canary islands and from Madeira // Arquipélago. Life and Marine Sciences. Vol.19A. P.33-54.

Sanamyan N.P., Sanamyan K.E. 1998. Some Actiniaria from the Commander Islands (Cnidaria: Anthozoa) // Zoosystematica Rossica. Vol.7. No.1. P.1-8.

Sanamyan N.P., Sanamyan K.E. 2006. The genera Urticina and Cribrinopsis (Anthozoa: Actiniaria) from the north-western Pacific // Journal of Natural History. Vol.40. No.7-8. P. 359-393.

Sanamyan N.P., Sanamyan K.E. 2009 (for 2008). [Shallow water anemones (Cnidaria: Actiniaria) from south-eastern coast of Kamchatka] // Invertebrate Zoology. Vol.5. No.2. P.155-172 [in Russian, with English summary].

Sanamyan N.P., Sanamyan K.E. 2010 (for 2009). [Anthozoans (Cnidaria: Anthozoa) found at the coasts of Starichkov Island] // Sanamyan K.E., Sanamyan N.P., Tokranov A.M., Cherniagina O.A. (eds.). Biota of Starichkov Island and adjacent waters of Avacha Gulf. Proceedings of Kamchatka Branch of Pacific Institute of Geography, Far Eastern Division, Russian Academy of Sciences. Petropavlovsk-Kamchatskii: Kamchatpress. No.8. P.208-226 [in Russian].

Sanamyan N.P., Sanamyan K.E. 2012. [Isopropanol mineral oil method in histology] // Bugaev F.V., Tokranov A.M., Cherniagina O.A. (eds.). Conservation of biodiversity of Kamchatka and coastal waters: materials of XIII international scientific conference, dedicated to the 75th anniversary of S.A. Dyrenkov's birthday. Petropavlovsk-Kamchatsky: Kamchatpress. P.155-159 [in Russian].

Sanamyan N.P., Sanamyan K.E. 2013. Edwardsia sojabio sp. n. (Cnidaria: Anthozoa: Actiniaria: Edwardsiidae), a new abyssal sea anemone from the Sea of Japan // Deep-Sea Research II. Vol.86-87. P.225-230.

Sanamyan N.P., Sanamyan K.E., Schories D. 2013. Actiniaria.com. Available from: http://actiniaria.com.

Sanamyan N.P., Sanamyan K.E., Tabachnick K.R. 2012. The first species of Actiniaria, Spongiactis japonica gen.n., sp.n. (Cnidaria: Anthozoa) an obligate symbiont of a glass sponge// Invertebrate Zoology. Vol.9. No.2. P.127-141.

Schmidt H. 1969. Die Nesselkapseln der Aktinien und ihre differentialdiagnostische Bedeutung // Helgoländer WissenschaftlicheMeeresuntersuchungen. Bd.19. S.284-317.

Schmidt H. 1972. Die Nesselkapseln der Anthozoen und ihre Bedeutung fur die phylogenetische Systematik // Helgoländer Wissenschaftliche Meeresuntersuchungen. Bd.23. S.422-458.

Schmidt H. 1974. On evolution in the Anthozoa // Proceedings of the Second International Coral Reef Symposium 1. Great Barrier Reef Committee, Brisbane, October, 1974. P.533-560.

Weill R. 1934. Contribution a l'Étude des Cnidaires et de leurs Nématocystes. Paris: Les Presses Universitaires de France. P.1-701.

Responsible editors: E.N. Temereva, K.G. Mikhailov 